\title{
FARMERS' WILLINGNESS TO PURCHASE CROP INSURANCE: EVIDENCE FROM WHEAT AND RASPBERRY SECTORS IN SERBIA
}

\author{
Žaklina Stojanović1, Tatjana Rakonjac-Antić2 ${ }^{2}$ Marija Koprivica ${ }^{3}$ \\ *Corresponding author E-mail: zaklina@ekof.bg.ac.rs
}

A R T I C L E I N F O
Review Article
Received: 27 September 2019
Accepted: 06 December 2019
doi:10.5937/ekoPolj1904107S
UDC 631.1.017.3:368.87]:633.11
(497.11)

Keywords:

yield insurance, revenue insurance, perceived risk, sustainability, discrete choice.

JEL: Q12, G22

\section{A B S T R A C T}

Crop insurance is widely acknowledged to be a valuable instrument contributing to sustainability of agriculture by reducing the risks associated with crop production and by stabilizing farmers' income. Despite the importance of the agricultural sector for the Serbian economy, level of crop insurance development is low. Therefore, there is a need to identify which characteristics most affect a farmer's decision regarding whether or not to use this type of insurance. In this study, a sample of 255 farmers producing wheat and raspberry in the regions of Vojvodina and Sumadija and Western Serbia were interviewed using structured questionnaire. The collected data was analyzed using the binomial logistic regression to ascertain the effects of selected socio-economic and risk perception variables on the likelihood that farmer plans to purchase crop insurance. Farmer's willingness to purchase crop insurance was found to be significantly influenced by age, farm size, income and perceived level of risk.

(C) 2019 EA. All rights reserved.

\section{Introduction}

Due to high risk and uncertainty, agricultural activity is highly vulnerable to the impact of external factors that are beyond the control of producers. Therefore, agricultural outcomes, compared to outcomes of other economic activities, are relatively less predictable. We have faced with more frequent and more intense adverse weather conditions due to climate change lately. Besides growing yield risk, agricultural producers are facing the risk of market price fluctuations as well. In such circumstances,

1 Žaklina Stojanović, Ph.D, Full Professor, University of Belgrade, Faculty of Economics, Kamenička 6 Street, 11000 Belgrade, Serbia, Phone: + 381113021 081, E-mail: zaklina@ ekof.bg.ac.rs, ORCID ID https://orcid.org/0000-0003-2878-9835.

2 Tatjana Rakonjac-Antić, Ph.D, Full Professor, University of Belgrade, Faculty of Economics, Kamenička 6 Street, 11000 Belgrade, Serbia, Phone: + 381113021074 , E-mail: rakonjacantic@ekof.bg.ac.rs , ORCID ID https://orcid.org/0000-0003-0371-0115

3 Marija Koprivica, Ph.D, Assistant Professor, University of Belgrade, Faculty of Economics, Kamenička 6 Street, 11000 Belgrade, Serbia, Phone: + 381113021 107, E-mail: marijajovovic@ekof.bg.ac.rs, ORCID ID https://orcid.org/0000-0003-4239-2252 
the importance of crop insurance as a risk management tool is increasing over time both for agricultural producers and agricultural policy makers. Crop insurance provides protection against the unexpected losses of projected crop yields (in the form of yield insurance) and covers expected revenue also from losses due to a fall in crop market prices (in the form of revenue insurance). If successful, crop insurance market could increase the viability of agriculture and reduce the need for publicly funded ad hoc disaster assistance programs (Coble \& Barnett, 2012).

Despite its falling share in the gross domestic product (from 7.1\% in 2011 to $5.7 \%$ in 2017), agriculture continues to be an important sector of Serbian economy. As agriculture still plays the most important role in rural development (so-called agrarian rural development), this sector significantly contributes to poverty reduction. Although agricultural performance is threatened by frequent crop failures and price volatility, the level of development of agricultural insurance, which mainly relates to crop insurance, is unsatisfactory. Low crop insurance market density and penetration rate give rise to a question about the determinants affecting the decisions of our farmers to insure their yields and revenues.

Purpose of the paper is to investigate factors influencing demand for crop insurance in Serbia and to recommend adequate policies for supporting the development of this type of insurance. The paper is structured as follows: first, characteristics of crop insurance market in Serbia with a focus on indicators of its development are analyzed; second, research methodology and the findings of previous empirical studies on factors influencing demand for crop insurance are elaborated; third, the research results are shown and discussed; and, finally, the main conclusions in the form of policy recommendations are presented.

\section{Crop insurance in Serbia}

Less than a half of 17 insurance companies operating in Serbia offer agricultural insurance products. Two basic forms of agricultural insurance are available on voluntary basis: crop insurance and animal insurance. Basic risks covered by crop insurance are hail, fire and thunderbolt, and with additional premium it is possible to provide coverage against supplementary risks such as windstorms, spring frost, autumn frost, floods and drought ${ }^{4}$ (Žarković et al., 2014). In addition to traditionally present yield insurance products that provide protection against loss of yield, insurance against loss of revenue has emerged recently as a new product on the market (offered only by one insurer for now).

As part of the incentive measures for rural development, the state began to subsidize insurance premium in 2007 for the registered agricultural holdings. By amending the Law on Incentives in Agriculture and Rural Development (2016, article 35), the minimum amount of incentives is reduced from $40 \%$ to $30 \%$ of the paid insurance

4 Insurance coverage against drought risk is provided by one insurance company and only for a limited number of crops for now. 
premium excluding VAT, starting from January 1, 2017. The maximum amount of incentives is $40 \%$ of the paid insurance premium, or $45 \%$ of the premium for farms located in less favoured arreas. In absolute terms, maximum amounts of incentives are: 100,000 RSD for insurance of agricultural crops; 500,000 RSD for insurance of vegetable crops, 1,000,000 RSD for insurance of fruit trees, vines and hops; 500,000 RSD for insurance of nursery gardens and/or young perennial plants and 2,000,000 RSD for insurance of animals. For all types of incentives, the beneficiary can achieve a maximum of 2,500,000 RSD in the total amount (Rules on conditions, method and application form for the exercise of rights on incentives for premium for insurance of crops, fruits, perennial plants, nursery gardens and animals, 2017, article 7). The amount of funds intended for insurance premium subsidies in the budget year 2018 was 150 million RSD, which is four times less than in 2017 (Regulation on the distribution of incentives in agriculture and rural development in 2017; 2018). At the same time, there is an opposite trend in the Member States of the European Union regarding the state incentives for the development of agricultural insurance. Since 2013, Member States may subsidize agricultural insurance premiums with support rate up to $65 \%$, under the condition that the losses covered represent more than $30 \%$ of the average annual production of the farmer (Regulation (EU) No 1305/2013 of the European Parliament and of the Council of 17 December 2013 on support for rural development by the European Agricultural Fund for Rural Development (EAFRD), article 37). As of 2018, the support rate is increased to $70 \%$, and the loss threshold is reduced to $20 \%$ (European Commission, 2017). Thus, the EU apparently has opted for a public-private partnership approach for agricultural insurance.

Figure 1. Number of policies of crop insurance and animal insurance in Serbia (2004-2018)

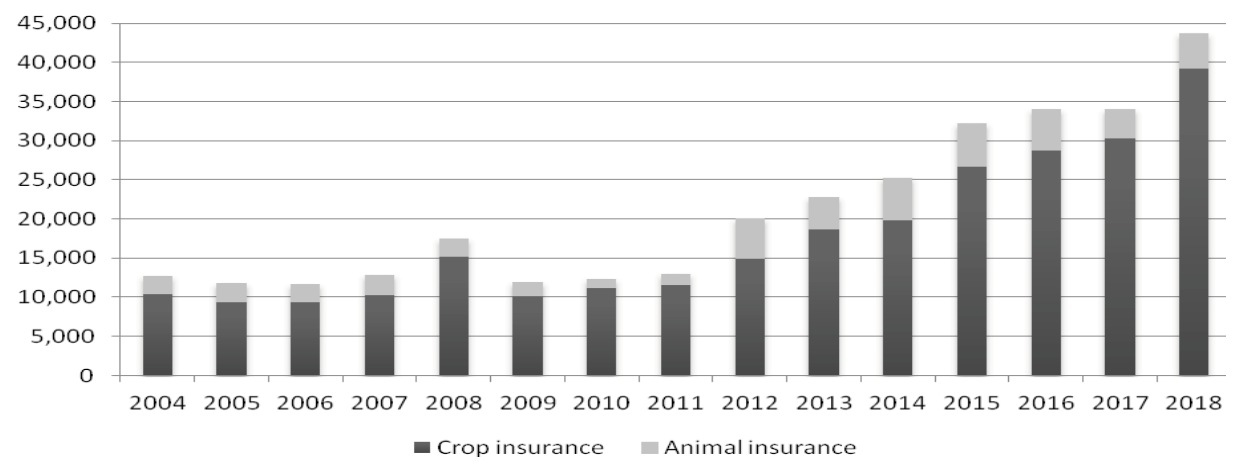

Source: National bank of Serbia. Number of insurances, policyholders and premiums by type of insurance and tariff for Serbia, https://www.nbs.rs/internet/english/60/60 2/index.html

Although there is no register of insured agricultural holdings at the state level, it is estimated that less than $10 \%$ of the total agricultural area and about $3 \%$ of the total number of agricultural holdings is covered by agricultural insurance (Radović, 2016). There were only 43,718 agricultural insurance policies in force in 2018, of which $89.7 \%$ referred to crop insurance (Figure 1). Gross written premium of crop insurance 
in the same year was about 3.4 billion RSD (28.4 million EUR), accounting for only $4.43 \%$ of total non-life insurance premium (National Bank of Serbia, 2019) (Figure 2).

Figure 2. Premiums written and technical result in crop insurance sector in Serbia (2004-2018)

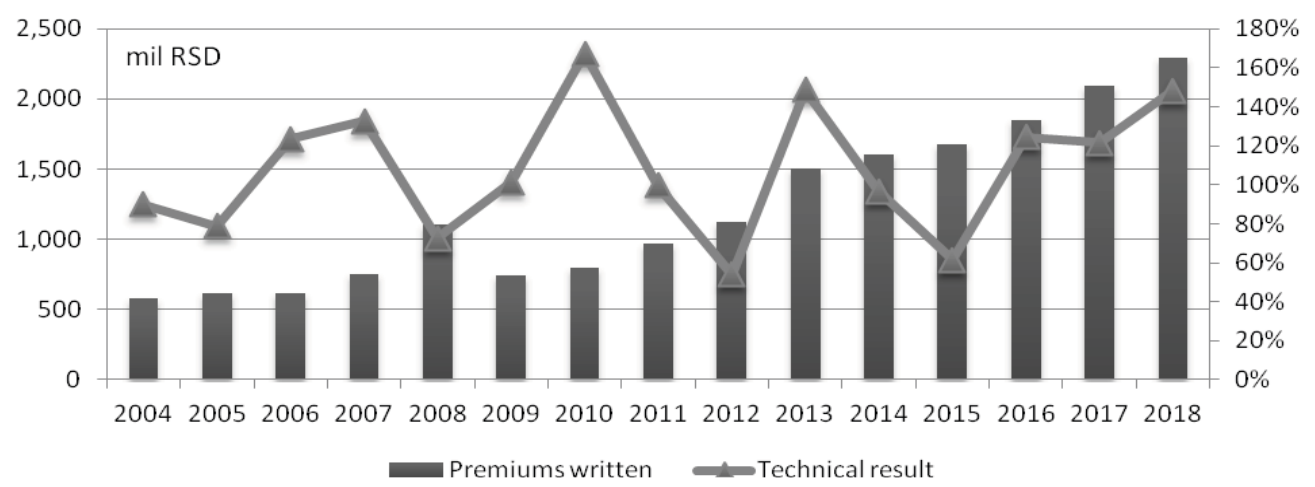

Source: National bank of Serbia. Number of insurances, policyholders and premiums by type of insurance and tariff and Number and amount of claims by types of insurance and tariff, https://www.nbs.rs/internet/english/60/60_2/index.html

Compared to 2004, the number of policies was more than tripled, and the crop insurance premium was almost quadrupled during the observed period. However,-the achieved result is not satisfactory. The baseline was extremely low, which invalidates the assessment of any significant shift in this type of insurance in the previous decade (Kočović et al., 2016). The underdevelopment of crop insurance in Serbia is even greater when compared with other countries in the region. Thus, for example, more than $50 \%$ of insurable agricultural area in Hungary and Bulgaria is insured (Bielza et al., 2008).

In accordance with the data presented, crop insurance penetration rate and insurance density, as the most conventional indicators of the development of an insurance market, are very low. Insurance penetration rate, as the ratio of annual premiums written to gross domestic product (GDP), measures contribution of the insurance sector to the national economy. In 2018, crop insurance penetration rate in Serbia amounted to only 0.17\% (National bank of Serbia, 2019; Statistical Office of the Republic of Serbia, 2019). Since only a small part of added value in agriculture is directed to the crop insurance sector (Marković et al., 2014), its participation in the GDP is peddling. Insurance density, as the ratio of annual premiums written to the whole population of a given country, indicates the average amount per capita spent on insurance. In the case of agricultural insurance, it is more convenient to relate premiums with the number of agricultural holdings (Petrović et al., 2013). Taking into account the total number of agricultural holdings determined by census of agriculture in 2012 (631,552) (Statistical Office of the Republic of Serbia, 2013), we obtained crop insurance density of 3,308.3 RSD (27.8 EUR). The value of this indicator is more favorable if we consider the number of registered agricultural holdings in $2018(449,452)$ (Ministry of Finance of the Republic of Serbia - Treasury Department) and is equal to 5,103.5 RSD (42.9 EUR). Considering that the total number of crop insurance policies in 2018 was only 39,212, 
it can be concluded that the average premium in this type of insurance amounted to 58,497.3 RSD (492.6 EUR) (National Bank of Serbia, 2019).

The situation regarding profitability of crop insurance business in Serbia is not so bright. By comparing claims with the earned technical premium, as a part of gross premium which is intended for risk coverage in a particular year, we obtain technical result (i.e. loss ratio), as a summary measure of the performance of insurance portfolio. Technical result lower than $100 \%$ indicates that the claim costs incurred in one year were covered by the technical premium earned in that year, and vice versa. Taking into account data on settled claims, technical result in crop insurance was higher than $100 \%$ in 7 of the past 15 years (Figure 2), indicating a loss in crop insurance business in those years. The result would be even more unfavorable if incurred claims (instead of settled claims) were included in calculation, as those claims reflect both the change of claims reserves and the costs of claims liquidation, which were not known to the authors. This indicator considerably varies over time as a result of highly unstable nature of the risks covered by this type of insurance. Finally, lower than $100 \%$ technical result does not necessarily imply an underwriting profit, since operating expenses of insurance companies also need to be covered.

Considered indicators reveal the unused potential for the development of crop insurance in Serbia. Undeveloped agriculture and low living standard of rural population (Stojanović et al., 2015), but also a low insurance culture and lack of awareness of potential policyholders (Kočović et al., 2016) are recognized as limiting factors in this regard. By increasing the number of policyholders, the average premium could be reduced, while the total premium at the same time would be increased. This would create the basis for sustainable development of agriculture, improving the performance of insurance companies and reducing the pressure on the state budget after the occurrence of natural disasters.

\section{Research methodology}

Our goal is to ascertain the effects of selected socio-economic and risk perception variables on farmer's willingness to purchase crop insurance, modeled using discrete choice framework. Risk management strategies in agriculture are heavily influenced by farmers' risk attitudes and farm characteristics reflecting farm's risk bearing capacity (Theuvsen, 2013). The choice of a combination of risk management instruments (including crop insurance) to adopt is one of the most fundamental and complex decisions an agricultural producer has to make (Velandia et al., 2009). Understanding the relationship between farm characteristics, farmers' risk perception and their willingness to use crop insurance is important for the decisional entities in determining strategies and formulating policies for agricultural development (Ullah et al., 2016). Also, knowledge about the factors affecting crop insurance demand outlines a consumer profile and thus can be useful for insurance companies to better adapt their offer to consumer needs. Although several rationales for the crop insurance decision were identified, a few variables are most prevalent across different studies, including those related to farmer's demographic attributes such as age (Dragos \& Mare, 2014, Akinola, 2014, Liesivaara \& Myyrä, 2014), gender (Mukhopadhyay et al, 2018, 
Mbonane \& Makhura, 2018) and education level (Danso-Abbeam et al, 2014, Black \& Dorfman, 2000), structural variables such as farm size (Sujarwo, 2017, Sherrick et al, 2004, Enjorlas \& Sentis, 2011, Lyu \& Barré, 2017), financial variables such as farm income (Wąs \& Kobus 2018, Farrin et al., 2016, Makki \& Somwaru, 2001, Blank \& McDonald, 1996, Goodwin, 1993), as well as variables indicating alternative risk management methods (diversification) and farmer's risk perception (Santeramo et al, 2016, Liu et al, 2016, Aditya et al, 2016, Di Falco et al, 2014, Sulewski \& KłoczkoGajewska, 2014, Enjolras et al, 2012, Wu, 1999).

Some studies analyzed determinants of demand for particular crop insurance products. By estimating a multinomial logit model of insurance choices facing U.S. farmers, Mishra \& Goodwin (2003) noticed that the set of significant explanatory variables is different for the adoption of yield versus revenue insurance. Education, farm size, and type of farm ownership were found to be statistically significant in explaining the decision to purchase revenue insurance, but the same variables were not found to be significant for the purchasing yield insurance. Contemporary academic literature is also concerned with factors affecting farmers' acceptance of some innovative insurance schemes, like index-based agricultural insurance (e.g. Kaczała \& Łyskawa, 2013; Cole et al., 2014; Isaboke et al. 2016).

Following a distinction between possible production- and market- related changes on wheat and raspberry farms, we consider respondents' willingness to purchase yield insurance and revenue insurance separately. In both cases, response variable $Y$ is categorical with two possible responses indicating whether or not an individual plans to purchase particular insurance product within next 5 years ("yes", when $Y=1$ and "no", when $Y=0$ ). In order to model probability that one of the outcomes occur, we employ binomial logistic regression which describes how a binary dependent variable is associated with one or more independent variables $X_{1}, X_{2}, \ldots, X_{k}$ that can be either continuous or categorical. For $p=\operatorname{Prob}(\mathrm{Y}=1 \mid \mathrm{X})$, the logit function is defined as $\log [p /(1-p)]$, where $p /(1-p)$ is the odds of an event occurring (i.e. log odds). As $p$ varies between 0 and 1 , logit function varies between $-\infty$ and $+\infty$ and it links the dependent variable to the set of explanatory variables:

$$
\log [p /(1-p)]=\beta_{0}+\beta_{1} \mathrm{X}_{1}+\cdots+\beta_{\mathrm{k}} \mathrm{X}_{\mathrm{k}}
$$

or equvalently:

$$
p=\frac{\exp \left(\beta_{0}+\beta_{1} \mathrm{x}_{1}+\cdots+\beta_{\mathrm{k}} \mathrm{x}_{\mathrm{k}}\right)}{1+\exp \left(\beta_{0}+\beta_{1} \mathrm{x}_{1}+\cdots+\beta_{\mathrm{k}} \mathrm{x}_{\mathrm{k}}\right)}
$$

where $\beta_{0}, \beta_{1}, \ldots, \beta_{k}$ are regression coefficients that are to be estimated by maximumlikelihood estimation (MLE) method. 
Thus, we estimated two logit models with two different dependent variables, representing farmers' willingness to purchase yield insurance and farmers' willingness to purchase revenue insurance. Independent variables in both models are the same, except that we included perceived market risk as an additional predictor in the second model. Choice of variables to represent a farmer's predisposition concerning crop insurance is based on preliminary evaluation of the survey data, a Mann-Whitney $U$ test and the results of earlier empirical researches.

Data used in this study come from a face to face survey of farmers producing wheat and raspberry in the regions of Vojvodina and Sumadija and Western Serbia, respectively, conducted in December 2017 - January 2018. The survey comprised of questions concerning demographic and business information, farming strategies, risk perceptions, and other related information useful in identifying the characteristics that may distinguish farmers who are willing to purchase insurance from those who are not willing. Sample representativeness was ensured through stratification by farm size and random selection of farms within each stratum. Total number of surveyed farmers is 271, of which 140 are wheat producers in Vojvodina and 131 are raspberry producers in Sumadija and Western Serbia. After removing the observations with missing values/ unanswered questions, a total of 255 observations per each variable were obtained.

\section{Results and discussion}

More than third (36.5\%) of the surveyed farmers were within the ages of 51 and 65 years. Also, about 29\% were in the age range of 41 and 50 years, and slightly less (27.8\%) were younger than 40 years. In terms of gender distribution, only $12.5 \%$ of respondents were female, which reflects gender imbalance in the Serbian agricultural sector. The largest group included respondents with lower secondary education $(65.1 \%)$, followed by higher secondary/vocational (13.3\%) and university education (12.5\%), while 9\% of respondents had only primary school. Only $12.9 \%$ of the surveyed farmers have a specific agricultural education. About $37 \%$ of respondents gave affirmative answer on the question whether they are planning to diversify into new crops in the coming 5 years. The average area of agricultural land was 57.59 ha. The average income in the latest completed financial year was calculated as 23,735.55 EUR.

Table 1 reports some descriptive statistics of variables in total and categorized by respondents' willingness to purchase yield insurance and revenue insurance. Out of 255 farmers sampled from the study area, 76 indicated their plan to purchase yield insurance, while 66 farmers acknowledged willingness to purchase revenue insurance, representing $29.8 \%$ and $25.9 \%$ of the sample, respectively. 
Table 1. Characteristics of surveyed farms

\begin{tabular}{|l|r|r|r|r|r|}
\hline \multirow{2}{*}{ Variable } & \multirow{2}{*}{ Tetal } & \multicolumn{2}{c|}{ Yield insurance } & \multicolumn{2}{c|}{ Revenue insurance } \\
\cline { 4 - 6 } & & \multicolumn{1}{c|}{ No } & \multicolumn{1}{c|}{ Yes } & \multicolumn{1}{c|}{ No } & \multicolumn{1}{c|}{ Yes } \\
\hline $\begin{array}{l}\text { Willingness to purchase particular insurance } \\
\text { product }\end{array}$ & $70.2 \%$ & $29.8 \%$ & $74.1 \%$ & $25.9 \%$ \\
\hline Age group & & & & & \\
\hline 40 or less years & $27.8 \%$ & $64.8 \%$ & $35.2 \%$ & $76.1 \%$ & $23.9 \%$ \\
\hline 41-50 years & $29.0 \%$ & $78.4 \%$ & $21.6 \%$ & $75.7 \%$ & $24.3 \%$ \\
\hline $51-65$ years & $36.5 \%$ & $69.9 \%$ & $30.1 \%$ & $74.2 \%$ & $25.8 \%$ \\
\hline More than 65 years & $6.7 \%$ & $58.8 \%$ & $41.2 \%$ & $58.8 \%$ & $41.2 \%$ \\
\hline Gender & & & & & \\
\hline Male & $87.5 \%$ & $69.1 \%$ & $30.9 \%$ & $71.7 \%$ & $28.3 \%$ \\
\hline Female & $12.5 \%$ & $78.1 \%$ & $21.9 \%$ & $90.6 \%$ & $9.4 \%$ \\
\hline Education level & & & & & \\
\hline Primary school & $9.0 \%$ & $69.6 \%$ & $30.4 \%$ & $69.6 \%$ & $30.4 \%$ \\
\hline Lower secondary & $65.1 \%$ & $72.3 \%$ & $27.7 \%$ & $74.1 \%$ & $25.9 \%$ \\
\hline Higher secondary/vocational & $13.3 \%$ & $61.8 \%$ & $38.2 \%$ & $70.6 \%$ & $29.4 \%$ \\
\hline University & $12.5 \%$ & $68.8 \%$ & $31.3 \%$ & $81.3 \%$ & $18.8 \%$ \\
\hline Specific qualifications & & & & & \\
\hline No & $87.1 \%$ & $71.2 \%$ & $28.8 \%$ & $73.9 \%$ & $26.1 \%$ \\
\hline Yes & $12.9 \%$ & $70.2 \%$ & $29.8 \%$ & $75.8 \%$ & $24.2 \%$ \\
\hline Plan to diversify & & & & & \\
\hline No & $63.1 \%$ & $75.8 \%$ & $24.2 \%$ & $80.1 \%$ & $19.9 \%$ \\
\hline Yes & $36.9 \%$ & $60.6 \%$ & $39.4 \%$ & $63.8 \%$ & $36.2 \%$ \\
\hline Total land area & 57.59 & 47.31 & 81.79 & 49.31 & 81.29 \\
\hline Income & 4.31 & 4.19 & 4.61 & 4.16 & 4.74 \\
\hline Perceived yield risk & 4.26 & 4.22 & 4.36 & 4.16 & 4.53 \\
\hline Perceived market risk & & $24,055.37$ & $23,599.76$ & $26,170.38$ & $22,885.30$ \\
\hline
\end{tabular}

Source: Authors' calculations.

During the survey, farmers were also asked to express to what extent different factors might influence their decisions regarding production and farming strategies on a 1 (not at all) to 5 (strongly) Likert scale. According to the results, adverse climatic conditions or pests and severe drops in market prices are considered among farmers to have the highest impact on the sustainability in the future (Figure 3). Thus, we can conclude that there is a relatively high level of risk perception among surveyed farmers. The average assigned score was 4.31 in case of yield risk, and 4.26 in case of market risk.

The means of total land area operated by farmers willing to purchase insurance exceeded those of their counterparts, while the situation is reversed in the case of household income. Among insurance products (i.e. yield and revenue insurance), average values of the same variables were similar. With regard to age group, proportion of those willing to purchase crop insurance is the highest among the oldest farmers (65>). Also, male farmers and farmers who plan to diversify into new crops are more willing to purchase crop insurance. The proportion of respondents planning to insure against crop losses and volatile prices is relatively constant among different educational levels. 
Further, specific agricultural qualifications did not seem to be statistically significant determinant of crop insurance purchase decision. Finally, farmers willing to purchase any crop insurance product exhibit relatively higher perceived yield risk, while perceived market risk seems to be related with farmers' decision to purchase revenue insurance, but not with the decision to purchase crop insurance. Thus, preliminary data analysis indicates some differences in the characteristics of farmers who are willing to purchase insurance and of those who are not.

Figure 3. Farmer's perceptions of different factors that will influence sustainability in the future

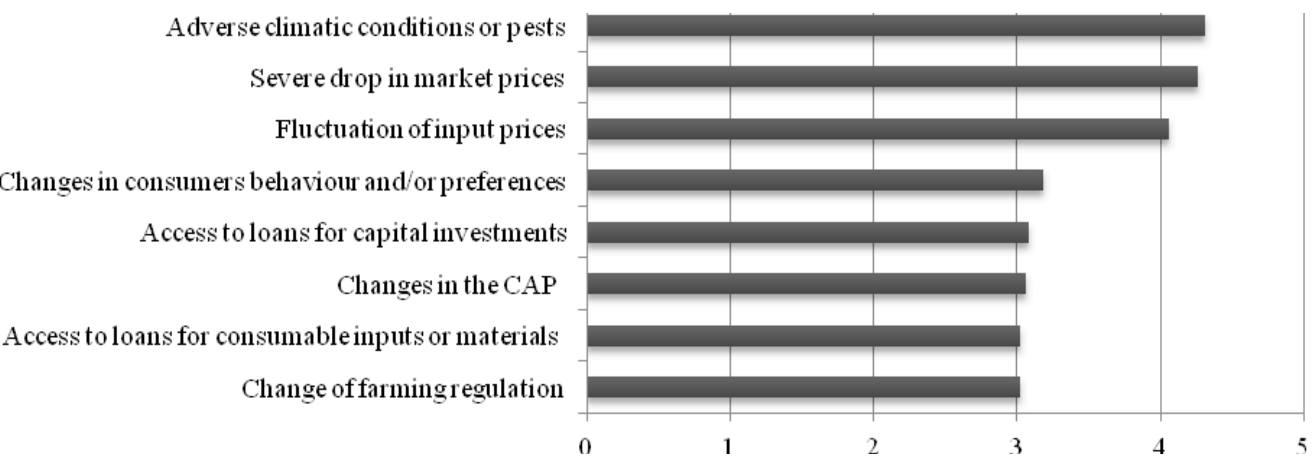

Source: Authors' calculations.

In order to determine if there are differences in terms of the risk perception between farmers who are willing to purchase crop insurance products and those who are not, we performed a Mann-Whitney $U$ test. Concerning decision to purchase revenue insurance, the two subsamples were significantly different with regard to median perceived yield risk and with regard to median perceived market risk, as well. On the other hand, farmers who plan to purchase yield insurance differ significantly from those who do not in terms of perceived yield risk, but not in terms of perceived market risk (Table 2).

Table 2. Results of the Mann-Whitney U test

\begin{tabular}{|c|r|r|r|r|r|r|r|r|}
\hline \multirow{2}{*}{$\begin{array}{c}\text { Grouping } \\
\text { Rariable }\end{array}$} & \multicolumn{4}{|c|}{ Yield insurance } & \multicolumn{3}{|c|}{ Revenue insurance } \\
\cline { 2 - 10 } & $\begin{array}{c}\text { Total } \\
\text { land } \\
\text { area }\end{array}$ & Income & $\begin{array}{c}\text { Perceiv. } \\
\text { yield risk }\end{array}$ & $\begin{array}{c}\text { Perceiv. } \\
\text { market } \\
\text { risk }\end{array}$ & $\begin{array}{c}\text { Total } \\
\text { land } \\
\text { area }\end{array}$ & Income & $\begin{array}{c}\text { Perceiv. } \\
\text { yield risk }\end{array}$ & $\begin{array}{c}\text { Perceiv. } \\
\text { market } \\
\text { risk }\end{array}$ \\
\hline $\mathrm{U}$ & 10,513 & 7,902 & 7,910 & 7,247 & 8,549 & 7,812 & 8,047 & 7,317 \\
\hline $\mathrm{Z}$ & 6.892 & 2.041 & 2.387 & 0.914 & 4.483 & 3.052 & 4.072 & 2.316 \\
\hline $\mathrm{P}$ & 0.000 & 0.041 & 0.017 & 0.361 & 0.000 & 0.002 & 0.000 & 0.021 \\
\hline
\end{tabular}

Note: Asymptotic significances are displayed. Variables significant at the 5\% level are in grey.

Source: Authors' calculations.

Such a result is logical given the risks covered by these two insurance products. Thus, we decided to include perceived yield risk variable in both and perceived market risk variable only in the second regression model. The same test also showed that median total land area and income were significantly different between farmers who are willing to purchase crop insurance products and farmers who are not. Thus, we decided to 
include those variables in both regression models, together with control variables (age group, gender, education level, specific qualifications and plan to diversify) to check if the identified differences are still significant.

In both logit regression models, linearity of the continuous independent variables with respect to the logit transformation of the dependent variable was assessed using the BoxTidwell (1962) approach. Two continuous variables that violated linearity assumption (total land area and income) were log transformed to achieve a linear relationship between variables. Multicollinearity was assessed by examining variance inflation factors (VIF) produced by multiple linear regression analysis with the same variables (Midi et al. 2013). VIF values were between 1 and 2 for all independent variables, indicating low correlation among them. Finally, cases with studentized residuals greater than \pm 2 standard deviations were removed from the analysis as outliers.

As shown in Table 3, the first logistic regression model was statistically significant. The model explained $66.6 \%$ (Nagelkerke R2) of the variance in farmers' willingness to purchase yield insurance and correctly classified $85.9 \%$ of cases. Sensitivity was $74.2 \%$, specificity was $90.3 \%$, positive predictive value was $74.2 \%$ and negative predictive value was $90.3 \%$. Four out of eight independent variables included in the model were found to be statistically significant: age group, perceived yield risk, $\ln$ (total land area) and $\ln$ (income).

The overall association between willingness to purchase yield insurance and farmer's age was significant at 5\% significant level, as indicated by the overall Wald statistic, but regression coefficients were not significant for all age groups, nor have the same signs. As opposed to farmers of 40 or less years, farmers within age group 41-50 years were less likely to buy yield insurance, while farmers older than 50 years were more likely to buy yield insurance. Thus, farmers older than 65 years had 22 times higher odds to be willing to buy yield insurance than farmers in the youngest group, after controlling for other predictors. The first result can be explained with the relative openness of younger farmers for new risk management tools and innovative approach in farming, while the second result is owed to the accumulated experience of older farmers enabling them to better understand the negative impact of farm perils on the performance of their production.

As expected, average perceived yield risk was higher for the group willing to purchase insurance, similar to the results reported by Sherrick et al. (2004), Liu et al. (2016) and Aditya et al. (2016). Increasing farm size measured by total land area was associated with an increased likelihood that farmer plans to buy yield insurance. This stands to imply that farmers operating larger farms are likely to experience relatively greater loss in absolute terms if peril such as hail, drought or flood occur than farmers with small ownership. Thus, they are more prone to yield insurance, although in relative terms the loss is greater for small farms (particularly in raspberry production) which are indeed usually less diversified, and the existence is more dependent on production results and therefore more vulnerable to natural disasters. This is also consistent with the previous studies (e.g. Enjorlas \& Sentis, 2011; Danso-Abbeam et al., 2014; Liesivaara \& Myyrä, 2014). 
Table 3. Logistic regression predicting likelihood of farmers ` willingness to purchase yield insurance based on selected variables

\begin{tabular}{|c|c|c|c|c|c|c|c|}
\hline Variable & B & & SE & Wald & df & $\mathbf{P}$ & $\begin{array}{l}\text { Odds } \\
\text { Ratio }\end{array}$ \\
\hline Constant & 4.932 & $*$ & 2.566 & 3.694 & 1 & 0.055 & 138.601 \\
\hline Age group & & & & 8.520 & 3 & 0.036 & \\
\hline $41-50$ years & -0.532 & & 0.573 & 0.862 & 1 & 0.353 & 0.588 \\
\hline 51-65 years & 0.763 & & 0.570 & 1.789 & 1 & 0.181 & 2.145 \\
\hline$>65$ years & 3.117 & $* *$ & 1.515 & 4.233 & 1 & 0.040 & 22.573 \\
\hline (reference group $=40$ or less & & & & & & & \\
\hline Gender & 1.603 & & 1.109 & 2.088 & 1 & 0.148 & 4.966 \\
\hline$($ reference group $=$ male $)$ & & & & & & & \\
\hline Education level & & & & 4.290 & 3 & 0.232 & \\
\hline Lower secondary & -0.909 & & 0.965 & 0.887 & 1 & 0.346 & 0.403 \\
\hline Higher secondary/Vocational & 0.654 & & 1.096 & 0.356 & 1 & 0.551 & 1.923 \\
\hline University & -0.624 & & 1.101 & 0.322 & 1 & 0.571 & 0.536 \\
\hline (reference group = primary) & & & & & & & \\
\hline Specific qualifications & -0.182 & & 0.632 & 0.083 & 1 & 0.773 & 0.833 \\
\hline (reference group $=$ yes) & & & & & & & \\
\hline Plan to diversify & -0.615 & & 0.496 & 1.539 & 1 & 0.215 & 0.541 \\
\hline (reference group = yes) & & & & & & & \\
\hline $\ln$ (Total land area) & 2.411 & $* * *$ & 0.438 & 30.277 & 1 & 0.000 & 0.165 \\
\hline $\ln ($ Income $)$ & -1.802 & $* *$ & 0.384 & 22.037 & 1 & 0.050 & 138.601 \\
\hline Perceived yield risk & 0.847 & $* * *$ & 0.220 & 14.756 & 1 & 0.000 & 2.332 \\
\hline Nagelkerke R Square & $66.6 \%$ & & & & & & \\
\hline Wald test & \multicolumn{7}{|c|}{$\chi^{2} \chi^{2}=148.444, \mathrm{df}=12, \mathrm{p}=0.000$} \\
\hline Hosmer \& Lemeshow test & \multicolumn{7}{|c|}{$\chi^{2} \chi^{2}=5.681, \quad \mathrm{df}=8, \quad \mathrm{p}=0.683$} \\
\hline Classification accuracy & \multicolumn{7}{|l|}{$85.9 \%$} \\
\hline
\end{tabular}

Note: $* * *, * *$ and $*$ indicate significance level at $1 \%, 5 \%$ and $10 \%$ level respectively.

Variables significant at the $5 \%$ level are in grey.

Source: Authors' calculations.

On the contrary, farmers' income was inversely related to the likelihood of planning to purchase yield insurance. In other words, recent yield losses decrease income from farming and thus increase farmer's willingness to buy insurance. This result is in line with the findings of Was \& Kobus (2018) and Mbonane \& Makhura (2018). However, it is contrary to the findings of Blank \& McDonald (1996), who reported positive correlation between income from farming and farmer's willingness to insure crops. It is logical to expect that with higher income insurance becomes more affordable, that is, farmers will be having more money to pay insurance premium which is usually believed to be beyond the reach of many poor among them. However, high income makes diverse risk management strategies available. Therefore, high-income farmers might opt to invest in better known risk management tools which compete against insurance. This leads to the conclusion that the lack of financial resources is not the http://ea.bg.ac.rs 
only cause of the low penetration and density of the crop insurance market in Serbia, because the interest in insurance is relatively low even when those funds exist. Rather, the farmers are not familiar enough with the benefits and importance of insurance, especially when they expect government help in case that natural disaster occurs.

Contrary to the expectations, other characteristics of the farmer, such as the gender, educational level, specific agricultural qualifications and willingness to diversify crop production have not been verified as statistically significant at a significance level of 5\%.

Table 4. Logistic regression predicting likelihood of farmers ' willingness to purchase revenue insurance based on selected variables

\begin{tabular}{|c|c|c|c|c|c|c|c|}
\hline Variable & B & & SE & Wald & df & $\mathbf{p}$ & $\begin{array}{l}\text { Odds } \\
\text { Ratio }\end{array}$ \\
\hline Constant & -5.175 & $*$ & 2.675 & 3.744 & 1 & 0.053 & 0.006 \\
\hline Age group & & & & 15.302 & 3 & 0.002 & \\
\hline $41-50$ years & -0.030 & & 0.598 & 0.003 & 1 & 0.910 & 0.970 \\
\hline $51-65$ years & 0.231 & & 0.565 & 0.167 & 1 & 0.682 & 1.260 \\
\hline$>65$ years & 3.915 & $* * *$ & 1.063 & 13.565 & 1 & 0.000 & 50.165 \\
\hline (reference group $=40$ or less years) & & & & & & & \\
\hline Gender & 0.108 & & 0.906 & 0.014 & 1 & 0.905 & 1.114 \\
\hline$($ reference group $=$ male $)$ & & & & & & & \\
\hline Education level & & & & 1.257 & 3 & 0.739 & \\
\hline Lower secondary & -0.855 & & 0.764 & 1.254 & 1 & 0.263 & 0.425 \\
\hline Higher secondary/College/Vocational & -0.705 & & 0.900 & 0.613 & 1 & 0.433 & 0.494 \\
\hline University & -0.776 & & 0.935 & 0.689 & 1 & 0.406 & 0.460 \\
\hline (reference group $=$ primary) & & & & & & & \\
\hline Specific qualifications & 0.073 & & 0.624 & 0.014 & 1 & 0.907 & 1.076 \\
\hline (reference group $=$ yes $)$ & & & & & & & \\
\hline Plan to diversify & 0.717 & & 0.474 & 2.288 & 1 & 0.130 & 2.048 \\
\hline (reference group = yes) & & & & & & & \\
\hline $\ln$ (Total land area) & 1.256 & **** & 0.243 & 26.688 & 1 & 0.000 & 3.510 \\
\hline $\ln$ (Income) & -0.938 & $* * *$ & 0.260 & 13.047 & 1 & 0.000 & 0.391 \\
\hline Perceived yield risk & 0.821 & $* * *$ & 0.317 & 6.724 & 1 & 0.010 & 2.273 \\
\hline Perceived market price risk & 1.133 & *** & 0.346 & 10.726 & 1 & 0.001 & 3.106 \\
\hline Nagelkerke R Square & $53.9 \%$ & & & & & & \\
\hline Wald test & \multicolumn{7}{|c|}{$\chi^{2} \chi^{2}=101.903, \mathrm{df}=13, \mathrm{p}=0.000$} \\
\hline Hosmer \& Lemeshow test & \multicolumn{7}{|c|}{$\chi^{2} \chi^{2}=3.181, \quad \mathrm{df}=8, \quad \mathrm{p}=0.922$} \\
\hline Classification accuracy & \multicolumn{7}{|l|}{$84.9 \%$} \\
\hline
\end{tabular}

Note: $* * *, * *$ and $*$ indicate significance level at $1 \%, 5 \%$ and $10 \%$ level respectively.

Variables significant at the $5 \%$ level are in grey.

Source: Authors' calculations.

As shown in Table 4, the second logistic regression model was also statistically significant. The model explained 53.9\% (Nagelkerke R2) of the variance in farmers' willingness to buy revenue insurance and correctly classified $84.9 \%$ of cases. Sensitivity was $58.8 \%$, 
specificity was $91.9 \%$, positive predictive value was $66.7 \%$ and negative predictive value was $89.1 \%$. Five predictor variables were found to be statistically significant: age group, $\ln$ (total land area), $\ln$ (income), perceived yield risk and perceived market risk.

Similarly to the previous model, in comparison with farmers of 40 or less years, farmers within age group 41-50 years were less likely to buy revenue insurance, while farmers older than 50 years were more likely to buy revenue insurance. Farmers older than 65 years had 50 times higher odds to be willing to buy revenue insurance than farmers younger than 40 years, after controlling for other predictors. Further, farmers willing to purchase revenue insurance operated significantly larger land areas, earned lower income in the previous financial year and exhibited higher perceived yield and market risk. The study revealed that, except the perceived market risk, all other factors influencing farmer's willingness to purchase yield and revenue insurance are the same. This finding confronts with the results reported by Mishra \& Goodwin (2003), who showed that several characteristics of farmers interested to insure against crop losses and volatile income are significantly different.

\section{Conclusion and policy recommendations}

In this paper we presented results of the investigation of factors affecting demand for crop insurance based on the evidence from wheat and raspberry sectors in Serbia. Two separate regression models were employed for this study, one to account for the yield insurance purchase decision and another to account for the revenue insurance purchase decision. Farmer's willingness to purchase crop insurance was found to be significantly influenced by age, farm size, income and perceived level of risk. On a basis of the estimates obtained, it is not possible to indicate clearly the relationship between the farmer's age and the willingness to insure yields or revenue. Thus, after a certain threshold, increasing farmer's age as a proxy of accumulated experience in farming is associated with increased odds of planning to buy crop insurance. It is also well known that older farmers groups are less prone to invest in new technologies and implement new instruments for risk insurance. The obtained results further show that farmers managing larger farms who have faced with lower income in the previous year, as well as farmers that perceive higher level of yield and market price risks, are more interested in buying crop insurance. Also, the study revealed that factors influencing farmer's willingness to purchase yield and revenue insurance are the same, except for the perceived market price risk which is relevant only for the decision to purchase revenue insurance.

The main factors affecting demand for crop insurance in Serbia are connected with financial resources available to farmers and their awareness on risk and insurance. From policy perspectives point of view, the obtained results suggest the need for further analysis of premium subsidies across market segments which could lead to a closer tailoring of premiums to farmer's attributes, especially in serving the needs for small and younger farmers. 
Considering the low level of crop insurance development, current subsidy rate of agricultural insurance premium should be changed. In order that large and high-risk farmers would not be favored, it is possible to introduce a differentiated instead of proportional premium subsidy rate. This rate can be higher for certain crops or regions where the development of agriculture is to be encouraged, for younger producers, smaller farms and multi-year insurance contracts. Also, in addition to premium subsidies, state subsidies that promote the development of market infrastructure, through investing in databases and risk models, subsidizing administrative costs for insurers, reinsurance and improving the relevant regulation are also highly recommended (Koprivica \& Rakonjac-Antić, 2019).

Based on the EU model, the public-private partnership should be a long-term commitment in terms of organizing agricultural insurance in Serbia. A possible solution for increasing penetration rate in the short term is the introduction of mandatory elements in agricultural insurance based on the targeted agricultural holdings categories. Following positive experiences from other countries, the obligation to insure can be selective, so that mandatory insurance is imposed on certain risks, for certain crops and/or for agricultural holdings whose size exceeds a certain limit. Also, the insurance obligation may be conditional in the sense obtaining publicly funded disaster assistance is conditioned with the possession of the insurance policy. In this way, the total risk would be distributed among a large number of policyholders, so that the cost of the insurance premium for each of them would be minimized.

Finally, a prerequisite for the premium rates to be adequate and crop insurance market to be sustainable even with strong public support is to develop a single database of losses in agriculture. Portfolios of individual insurers in Serbia are relatively small, which limits the accuracy of risk assessment and makes it difficult to calculate actuarially funded premiums, while the cooperation between companies in the domain of data exchange is completely underdeveloped. Therefore, an initiative by the Association of Serbian Insurers is needed to create a unified database of losses in agriculture as a basis for calculating adequate premiums and developing new insurance products. By virtue of the bonus-malus system that exists in motor third-party liability insurance, insurers could, for each new policyholder who was previously insured with another insurer, find out her/his loss experience and accordingly determine the insurance premium. Even if crop insurance becomes mandatory, tariff determination should remain in the domain of insurance companies, but with the improvement of the grounds on which it is based.

Obtained results also highlight the need for more intense educational programs and marketing campaigns supported by authorities or private entities about the importance and benefits of crop insurance. If farmers would be more knowledgeable about crop insurance, they will be able to recognize its advantages over other risk management instruments and to better understand insurance policies and conditions and thus gain greater confidence in insurance. Marketing programs targeted to younger farmers and small farms operators will likely be more successful in contributing to the wider adoption of crop insurance in Serbia. 


\section{Acknowledgements}

Paper is a part of research within the SUFISA Project. This project has received funds from the EU's Horizon 2020 research and innovation programme under Grant Agreement No 635577.

\section{Conflict of interests}

The authors declare no conflict of interest.

\section{References}

1. Aditya, K. S., Tajuddin, K., \& Avinash, K. (2016). Crop Insurance in India: Drivers and Impact. 2016 Annual Meeting, July 31-August 2, Boston, MA, Agricultural and Applied Economics Association, DOI:10.13140/RG.2.1.1012.0562

2. Akinola, B. D. (2014). Determinants of Farmers'Adoption of Agriculture Insurance: the Case of Poultry Farmers in Abeokuta Metropolis of Ogun State, Nigeria. British Journal of Poultry Sciences, 3(2), 36-41, DOI: 10.5829/idosi.bjps.2014.3.2.83216

3. Bielza, M., Conte, C., Dittmann, C., Gallego, J., \& Stroblmair, J. (2008). Agricultural Insurance Schemes. European Commission, Joint Research Centre, Ispra.

4. Black, D. K., \& Dorfman, J. H. (2000). Identifying Farmer Characteristics Related to Crop Insurance Purchase Decisions. 2000 Annual meeting, July 30-August 2, Tampa, FL, American Agricultural Economics Association, DOI: 10.22004/ag.econ.21831

5. Blank, S. C., \& McDonald, J. (1996). Preferences for Crop Insurance When Farmers Are Diversified. Agribusiness, 12(6), 583-592, DOI: 10.22004/ag.econ.291738

6. Box, G. E. P., \& Tidwell, P. W. (1962). Transformation of the independent variables. Technometrics 4, 531-550, DOI: 10.2307/2526842

7. Coble, K., \& Barnett, B. J. (2012). Why Do We Subsidize Crop Insurance? American Journal of Agricultural Economics, 95(2), 498-504, DOI: https://doi.org/10.1093/ ajae/aas093

8. Cole, S., Stein, D., \& Tobacman, J. (2014). Dynamics of Demand for Index Insurance: Evidence from a Long-Run Field Experiment. American Economic Review, 104(2014), 284-290, DOI: 10.1257/aer.104.5.284

9. Danso-Abbeam, G., Addai, K. N., \& Ehiakpor, D. (2014). Willingness to Pay for Farm Insurance by Smallholder Cocoa Farmers in Ghana. Journal of Social Science for Policy Implications, 2(1), 163-183.

10. Di Falco, S., Adinolfi, F., Bozzola, M., \& Capitanio, F. (2014). Crop Insurance as a Strategy for Adapting to Climate Change. Journal of Agricultural Economics, 65(2), 485-504, DOI: 10.1111/1477-9552.12053

11. Dragos, S. L., \& Mare, C. (2014). An Econometric Approach to Factors Affecting Crop Insurance in Romania. Ekonomie a Management, 17(1), 93-104, DOI: http:// dx.doi.org/10.15240/tul/001/2014-1-008 
12. Enjolras, G., Capitanio, F., \& Adinolfi, F. (2012). The demand for crop insurance: combined approaches for France and Italy. Agricultural Economics Review, 13(1), 5-22, DOI: 10.22004/ag.econ.253490

13. Enjorlas, G., \& Sentis, P. (2011). Crop insurance policies and purchases in France. Agricultural Economics, 42(2011), 475-486, DOI: 10.1111/j.1574-0862.2011.00535.x

14. European Commission (2017). Summary of main changes introduced to the four basic regulations of the CAP through the Omnibus regulation, Brussels, https:// ec.europa.eu/agriculture/cap-overview/summary-changes-omnibus en.pdf (accessed 10.02.2019)

15. Farrin, K., Miranda, M. J., \& O’Donoghue, E. (2016). How Do Time and Money Affect Agricultural Insurance Uptake? A New Approach to Farm Risk Management Analysis. Economic Research Report.

16. Goodwin, B. K. (1993). An Empirical Analysis of the Demand for Multiple Peril Crop Insurance. American Journal of Agricultural Economics, 75(2), 425-434, DOI: https://doi.org/10.2307/1242927

17. Isaboke, H. N., Zhang, Q., Nyarindo, W. N., \& Wang, K. (2016). Factors explaining producer perception towards weather index micro-insurance: Evidence from Kenya. RUFORUM Working Document Series, 14(3), 345-354.

18. Kaczała, M., \& Łyskawa, K. (2013). Factors affecting the demand for index-based agriculture insurance in Poland. Insurance Review, 4(2013), 75-91.

19. Kočović, J., Rakonjac-Antić, T., \& Jovović, M. (2016). Possibilities for Agricultural Insurance Development in Serbia, print in ed. Stojanović Ž. And Bogdanov N., Agribusiness and villages in Serbia - state and perspectives, Facutly of Economics, University of Belgrade, pp. 205-224. [in Serbian: Kočović, J., Rakonjac - Antić, T., \& Jovović, M. (2016). Mogućnosti razvoja osiguranja poljoprivede u Srbiji, objavljeno u Stojanović, Ž., Bogdanov, N. (red.), Stanje i perspektive agroprivrede i sela u Srbiji, Ekonomski fakultet, Univerzitet u Beogradu].

20. Koprivica, M., \& Rakonjac - Antić, T. (2019). Insurance development in agriculture in Serbia and EU countries, Ekonomski vidici, XXIV(1-2), 43-58 [in Serbian: Koprivica, M., \& Rakonjac-Antić, T., (2019). Razvijenost osiguranja u poljoprivredi u Srbiji i u zemljama Evropske unije].

21. Law on Incentives in Agriculture and Rural Development. Official Gazette of the Republic of Serbia, No. 10/2013, 142/2014, 103/2015 and 101/2016.

22. Liesivaara, P., \& Myyrä, S. (2014). Willingness to pay for agricultural crop insurance in the northern EU. Agricultural Finance Review, 74(4): 539-554, DOI: 10.1108/AFR-06-2014-0018

23. Liu, F., Corcoran, C. P., Tao, J., \& Cheng, J. (2016). Risk perception, insurance recognition and agricultural insurance behavior - An empirical based on dynamic panel data in 31 provinces of China. International Journal of Disaster Risk Reduction, 20(2016): 19-25, DOI: 10.1016/j.ijdrr.2016.10.005 
24. Lyu, K., \& Barré, T. J. (2017). Risk aversion in crop insurance program purchase decisions: Evidence from maize production areas in China. China Agricultural Economic Review, 9(1), 62-80, DOI: 10.1108/CAER-04-2015-0036

25. Makki, S. S., \& Somwaru, A. (2001). Asymmetric Information in the Market for Yield and Revenue Insurance Products. Technical Bulletins 33587, U. S. Department of Agriculture, Economic Research Service, Washington, D. C., DOI: 10.22004/ ag.econ.33587

26. Marković, T., Martinovska Stojcheska, A., Zgajnar, J., \& Janeska Stamenkovska, I. (2014). Crop insurance as a factor of economic stability in the agriculture -The case of Serbia, Slovenia and Macedonia. 9th International Conference: The role of agricultural economic sciences in agriculture and rural development in the Balkan countries, 24-25 April 2014, Ohrid, Association of Agricultural Economists of Republic of Macedonia.

27. Mbonane, N. D., Makhura, M. N. (2018). Factors influencing maize farmers' interest in crop insurance in Swaziland. SA-TIED Working paper 15, Washington, D. C.: International Food Policy Research Institute.

28. Midi, H., Sarkar, S., \& Rana, S. (2013). Collinearity diagnostics of binary logistic regression model. Journal of Interdisciplinary Mathematics, 13(3), 253-267, DOI: 10.1080/09720502.2010.10700699

29. Ministry of Finance of the Republic of Serbia - Treasury Department. Register of agricultural holdings - Statistics, http://www.trezor.gov.rs/sr/services/rpg/statistika (accessed 26.09.2019)

30. Mishra, A. K., \& Goodwin, B. K. (2003). Adoption of Crop versus Revenue Insurance: A Farm-Level Analysis. Agricultural Finance Review, 63(2), 143-155, DOI: $10.1108 / 00215050380001146$

31. Mukhopadhyay, P., Sinha, M., \& Sengupta, P. P. (2018). Determinants of Farmers' Decision-Making to Accept Crop Insurance: A Multinomial Logit Model Approach. In Soft Computing in Data Analytics: Proceedings of International Conference on SCDA 2018, Nayak, J., Abraham, A., Krishna, B. M., Sekhar, G. T. C., \& Das, A. K. (eds.), Springer, 267-275, DOI: 10.1007/978-981-13-0514-6_27

32. National bank of Serbia. Number and amount of claims by types of insurance and tariff, https:/www.nbs.rs/internet/english/60/60_2/index.html (accessed 26.09.2019)

33. National bank of Serbia. Number of insurances, policyholders and premiums by type of insurance and tariff for Serbia, available at https://www.nbs.rs/internet/ english/60/60_2/index.html (accessed 26.09.2019)

34. Petrović, Z., Njegomir, V., \& Počuča, S. (2013). Characteristics of agricultural insurance: the case of countries of former Yugoslavia region. Economics of Agriculture, 4(2013), 729-743. 
35. Radović, G. (2016). Agricultural insurance as the obligatory insurance in the Republic of Serbia, Tokovi osiguranja 4 (2016): 7-23 [in Serbian: Radović, G. (2016). Osiguranje poljoprivrede kao moguće obavezno osiguranje u Republici Srbiji. Tokovi osiguranja, 4(2016): 7-23]

36. Regulation (EU) No 1305/2013 of the European Parliament and of the Council of 17 December 2013 on support for rural development by the European Agricultural Fund for Rural Development (EAFRD), Official Journal of the European Union, 347.

37. Regulation on the distribution of incentives in agriculture and rural development in 2017. Official Gazette of the Republic of Serbia, No. 106/2017.

38. Regulation on the distribution of incentives in agriculture and rural development in 2018. Official Gazette of the Republic of Serbia, No. 18/2018.

39. Rules on conditions, method and application form for the exercise of rights on incentives for premium for insurance of crops, fruits, perennial plants, nursery gardens and animals. Official Gazette of the Republic of Serbia, No. 61/17.

40. Santeramo, F. G., Goodwin, B. K., Adinolfi, F., \& Capitanio, F. (2016). Farmer Participation, Entry and Exit Decisions in the Italian Crop Insurance Programme. Journal of Agricultural Economics, 67(3), 639-657, DOI: https://doi.org/10.1111/1477-9552.12155

41. Sherrick, B. J., Peter J. B., Ellinger, P. N., \& Schnitkey, G. D. (2004). Factors Influencing Farmers' Crop Insurance Decisions. American Journal of Agricultural Economics, 86(1), 103-114, DOI: https://doi.org/10.1111/j.00925853.2004.00565.x

42. Statistical Office of the Republic of Serbia (2013). Census of Agriculture 2012 Agriculture in the Republic of Serbia, Belgrade.

43. Statistical Office of the Republic of Serbia (2018). Ekonomski računi poljoprivrede u Republici Srbiji, 2007-2017. Belgrade.

44. Statistical Office of the Republic of Serbia, https://www.stat.gov.rs/en-US (accessed 26.09.2019)

45. Stojanović, Ž., Gligorijević, M., Rakonjac-Antić, T. (2012): The Role of the Marketing Mix in the Improvement of Agricultural Insurance. Economics of Agriculture, [S.1.], v. 59, n. 4, 769-780, DOI: 10.22004/ag.econ. 143172

46. Stojanović, Ž., Popović Petrović, I., \& Rakonjac-Antić, T. (2015). The impact of catastrophe risks on agricultural sector in Serbia, print in ed. Kočović, J., Jovanović Gavrilović, B., Đukić, V., Catastrophic risks and sustainable development, Faculty of Economics, University of Belgrade, 267-284.

47. Sujarwo, S. (2017). Factors affecting farmers' acceptability toward agricultural insurance program in Malang, East java, Indonesia. Agricultural Socio-Economics Journal, 17(3), 97-104, DOI: https://doi.org/10.21776/ub.agrise.2017.017.3.1

48. Sulewski, P., \& Kłoczko-Gajewska, A. (2014). Farmers' risk perception, risk aversion and strategies to cope with production risk: an empirical study from Poland. Studies in Agricultural Economics, 116(2014), 140-147, DOI: 10.7896/j.1414 
49. Theuvsen, L. (2013). Risk and risk management in agriculture. Problems of world agriculture, 13(4), 162-174, DOI: 10.1504/IJRAM.2000.001491

50. Ullah, R., Shivakoti, G. P., Zulfiqar, F., \& Kamran, M. A. (2016). Farm risks and uncertainties: Sources, impacts and management. Outlook on Agriculture, 45(3), 199-205, DOI: 10.1177/0030727016665440

51. Velandia, M., Rejesus, R. M., Knight, T. O., \& Sherrick, B. J. (2009). Factors affecting farmers' utilization of agricultural risk management tools: the case of crop insurance, forward contracting and spreading sales. Journal of Agricultural and Applied Economics, 41(1), 107-123, DOI: https://doi.org/10.1017/ S1074070800002583

52. Wąs, A., \& Kobus, P. (2018). Factors differentiating the level of crop insurance at Polish farms. Agricultural Finance Review, 78(2), 209-222, DOI: https:/doi. org/10.1108/AFR-06-2017-0054

53. Wu, J. (1999). Crop Insurance, Acreage Decisions, and Nonpoint-Source Pollution. American Journal of Agricultural Economics, 81(2), 305-320, DOI: https://doi. org/10.2307/1244583

54. Žarković, N., Toscano, B., Mrkšić, D., \& Lisov, M. (2014). Key features of crop insurance in Serbia. Bulgarian Journal of Agricultural Science, 20(1), 23-33. 
